\title{
The Relationship between Thinking Styles and the Need for Cognition of Students in the Faculty of Education
}

\author{
Nesrin Uyanık Sağlam ${ }^{1}$ \& Erhan Tunç ${ }^{2}$ \\ ${ }^{1} 23$ Nisan Primary School, Mersin, Turkey \\ ${ }^{2}$ Faculty of Education, Gaziantep University, Gaziantep, Turkey \\ Correspondence: Erhan Tunç, Faculty of Education, Gaziantep University, Gaziantep, Turkey. E-mail: \\ erhantunc25@gmail.com
}

Received: June 26, 2018

Accepted: July 30, 2018

Online Published: October 22, 2018

doi:10.5539/ies.v11n11p1

URL: https://doi.org/10.5539/ies.v11n11p1

\begin{abstract}
This study aims to identify the relationship between thinking styles and the need for cognition in students of the faculty of education, as well as the existence of significant differences between these two variables according to gender, department of study, class level, educational background from secondary school level, monthly incomes of families and the place where families have resided longest. The study was conducted with 820 students studying at different departments of the Faculty of Education at Gaziantep University, during the 2014-2015 academic year. In the study, data was collected using the Thinking Styles Scale and the Need for Cognition Scale, while demographic details of students were obtained through a Personal Information Form created by the researcher. Pearson's correlation test, t-test and one-way analysis of variance (ANOVA) were employed in SPSS 20 software for data analysis. According to the findings of the study, students of the education faculty use the legislative thinking style the most and the conservative thinking style the least among the others given in the Thinking Styles Scale. According to the findings regarding the relationship between thinking styles and the need for cognition; the Thinking Styles Scale shows that there are significant differences between the legislative, executive, judicial, hierarchic, oligarchic, anarchic, local, internal, liberal dimensions of thinking and the need for cognition, while there is no significant difference between the global and conservative thinking styles and the need for cognition. It is seen that legislative, executive and hierarchic dimensions of the Thinking Styles Scale differ significantly according to the gender variable. Local, conservative and oligarchic dimensions of the Thinking Style Scale also show significant differences according to the department where the students study. This differentiation is seen in favor of the classroom teaching department against the Psychological Counselling and Guidance (PCG) students in the local thinking style dimension, while it is more favorable for the mathematics teaching department against the PCG students in both conservative and oligarchic dimensions. It is also seen that the legislative and local dimensions of the Thinking Styles Scale differ significantly according to the monthly incomes of families. This differentiation is in favor of the $2000 \mathrm{TL}$ and above income group in each of these thinking styles, against those with monthly incomes between 500-1000 TL. On the other hand, the place where families have resided the longest, which is often the same place where students have completed their secondary education, do not differ significantly according to class levels. The Need for Cognition Scale scores differ significantly in favor of the 4th grade students according to the class level variable. A similar significant differentiation in the Need for Cognition Scale scores is also seen in favor of urban areas (provinces) against rural areas (villages) according to the place where families have resided the longest. Finally, the Need for Cognition Scale scores do not show any significant difference in terms of the departments students study at, their secondary school majors and monthly incomes of families.
\end{abstract}

Keywords: individual factors, thinking styles, need for cognition

\section{Introduction}

Thinking is a life-long activity that helps individuals interpret complex matters in a simple way, whilst being a key to a number of gates within brain's gyri. In its most common aspect, thinking is a function that distinguishes a human-being from all other creatures, and it is often defined as follows: "Thinking is a disciplined way of conceptualization, implementation, analysis and interpretation of the knowledge obtained through observation, experience, intuition, reasoning, and other channels." (Özden, 2005, p. 139)

Recently, the idea that thinking is learnable has been suggested together with a number of approaches to improve 
the thinking process. People should act with a planned and systematic approach and increase their awareness in order to benefit the act of thinking. In this way, they can also reach a deeper level of thinking (Tok, 2010; Akman, 2016). From this aspect, thinking is considered as a teachable skill. In educational environments, teachers should not only perform the act of teaching but also train their students to approach problems in a critical way, expose their creativity and generate solutions for problems.

Every individual tends to choose a profession that matches not only with his/her skills but also his/her thinking styles. This idea is the reason behind the fact that some students who are placed in the same university and department with similar scores, fail a number of courses by the end of first semester, and cannot even complete the degree successfully. In addition, students with similar skills may opt for different professions after graduation and those who are expected as future engineers or doctors may be successful artists several years later. As success in professions, education and many other fields cannot only be explained with skills, thinking styles have been a popular alternative research subject so as to explore individual differences that lay the foundation for success (Karabulut, 2014; Akman, 2017).

The thinking styles that dominate daily lives are also seen in educational environments. Accordingly, the thinking styles of teachers and of students, the first two significant factors in learning and teaching processes, are significant variables (Özbaş \& Uluçınar, 2014).

In order to ensure a student-oriented and efficient process of learning, first, the teachers should recognize their own thinking styles and the importance of thinking styles for their students. The thinking styles of teachers should be taken into consideration in order to ensure an efficient teaching process. A teaching process which is in line with the teacher's own thinking styles would be more suitable for the teacher themselves and therefore be potentially effective, efficient and fruitful (Oflar, 2010; Akman \& Alagoz, 2017). In addition, as the need for cognition involves the skills required of a teacher, it is important to recognize the level of the teachers' need for cognition and to take necessary steps to fill the identified gaps in this regard (Tok, 2010).

Table 1. General characteristics of thinking styles (Sternberg, 1994; Park et al., 2005; Fer, 2005 as cited in Dinçer, 2009)

\begin{tabular}{|c|c|c|}
\hline $\begin{array}{l}\text { Thinking } \\
\text { Styles }\end{array}$ & Characteristics of Thinking Styles & General Characteristics \\
\hline \multicolumn{3}{|l|}{ Functions } \\
\hline Legislative & $\begin{array}{l}\text { Creative, inventive, innovative, ideogenetic, } \\
\text { self-driven. }\end{array}$ & $\begin{array}{l}\text { Interested in science projects, poems, story-writing, creating } \\
\text { original art works. }\end{array}$ \\
\hline Executive & $\begin{array}{l}\text { Conformist, prefers to do whatever is needed to be } \\
\text { done. }\end{array}$ & Interested in solving problems, writing about a certain issue. \\
\hline Judicial & Likes judging and assessing. & Likes criticizing others' acts, giving feedback and advice. \\
\hline \multicolumn{3}{|l|}{ Forms } \\
\hline Monarchic & $\begin{array}{l}\text { Focuses on a single activity and targets using all } \\
\text { available power. }\end{array}$ & $\begin{array}{l}\text { Likes focusing on a single project, regardless it is about science, } \\
\text { history, arts etc. }\end{array}$ \\
\hline Hierarchic & $\begin{array}{l}\text { Makes use of the time well enough to perform more } \\
\text { than one task at the same time. }\end{array}$ & $\begin{array}{l}\text { Likes allocating the power/energy to different activities according to } \\
\text { the order of priority. }\end{array}$ \\
\hline Oligarchic & $\begin{array}{l}\text { Performs more than one task at once and fails in } \\
\text { prioritizing. }\end{array}$ & $\begin{array}{l}\text { Likes spending time on reading comprehension questions but may } \\
\text { not complete standard verbal-skill tests. }\end{array}$ \\
\hline Anarchic & $\begin{array}{l}\text { Adopts random approaches toward problems and } \\
\text { avoids systems and guidance. }\end{array}$ & $\begin{array}{l}\text { Skips from one subject to another while speaking, starts but cannot } \\
\text { complete activities. }\end{array}$ \\
\hline \multicolumn{3}{|l|}{ Levels } \\
\hline Global & $\begin{array}{l}\text { Focuses on the whole picture, general perspective } \\
\text { and abstract thoughts. }\end{array}$ & $\begin{array}{l}\text { Interested in writing messages and creating art works that give } \\
\text { wholistic messages. }\end{array}$ \\
\hline Local & Focuses on details, subjective and concrete thoughts. & Interested in writing to describe details of art. \\
\hline \multicolumn{3}{|l|}{ Scope } \\
\hline Internal & $\begin{array}{l}\text { Likes studying/working alone, introvert, } \\
\text { self-sufficient. }\end{array}$ & Likes doing on their own. \\
\hline External & $\begin{array}{l}\text { Likes studying/working with others, social, } \\
\text { extrovert, mutually dependent. }\end{array}$ & Prefers projects that enables team work. \\
\hline Trends & & \\
\hline
\end{tabular}




\begin{tabular}{lll}
\hline Liberal & Likes trying new methods, resists traditions. & Can find how to use a tool even if there are no instructions. \\
\hline Conservative & $\begin{array}{l}\text { Likes adopting tested and correct methods, } \\
\text { traditionalist. }\end{array}$ & $\begin{array}{l}\text { Prefers using a tool with traditional and tested methods, as well as } \\
\text { studying at traditional classroom environments. }\end{array}$ \\
\hline
\end{tabular}

\subsection{Thinking Styles}

Thinking styles are behaviors and trends adopted by individuals through cognitive processes maintained in case of problems, different situations and in existence of different variables (Sünbül, 2004).

According to Sternberg (1997), every human-being intrinsically engages in the act of constant thinking, but thinking processes may differ from person to person and a thinking process is often unique to a specific individual. Just as individuals differ according to their appearance, hobbies, preferences, styles and cultures, they also show differences in their cognitive initiatives (mental schema), as well as learning and thinking activities (styles). Differences in thinking styles often lead individuals to expose their skills in different ways and show different reactions.

There are three known approaches that are based on thinking styles. The first of these approaches is Epstein's Cognitive Experiential Self Theory, the second approach is Myers and Briggs' personality theory that classifies the types of personality based on Jung's studies, and the third approach is Sternberg's Mental Self-Management Theory, developed in the early 1990s and is widely used in today's literature (Karabulut, 2014). This study used the Mental Self-Management Theory to examine thinking styles.

According to the main idea of the Mental Self-Management Theory, state organizations (forms), established to ensure the social order, are not accidental formations. Taking the self-governance system as an analogy, this theory suggests that individuals are in need of governing themselves and regulating their own daily activities just as societies are (Buluş, 2005). In other words, this theory supports the idea that regulatory behaviors of individuals show parallelism with those of societies.

Sternberg is the most focused researcher within the literature about the concept of thinking style and gives the greatest number of details about it amongst others. According to Sternberg (1997), the concept of thinking style has certain characteristics and they are about the meaning and use of the concept itself (as cited in Ariol, 2009).

Sternberg suggests the following principles regarding the thinking styles:

1) Styles are preferences, not abilities.

2) Each individual has a profile of styles, rather than a single style.

3) Styles may vary across tasks and situations.

4) Individuals may show flexibility in the skills they have and the level of flexibility may vary from person to person. Flexibility in skills helps individuals adapt to different situations.

5) Styles may experience a lifelong diversification.

6) Styles are measurable.

7) Styles are socialized.

8) Styles are teachable.

9) Styles are not good, normal or bad.

10) Life preferences should be coherent with thinking styles as much as they are with skills.

11) What is valued in a time and place may not be valued in another.

\subsection{Need for Cognition}

"The act of thinking and the tendency to enjoy the situation" has always been a part of personality and social psychology throughout the history (Asch, 1946; Murphy, 1947; Sarnoff \& Katz, 1954 as cited in Arpac1, 2015). The nature, acquisition and use of knowledge have been the foundation of cognitive studies. In this regard, Murphy studied individuals with a similar tendency and Katz described them as "people who are in search of understanding". However, as the starting point of Gestalt models, the "need for cognition" concept was suggested by Cohen, Stotland and Wolfe. The need for cognition has a significant place in empirical studies in social sciences, which are often conducted with undergraduate degree students. The other fields relevant to the need for cognition are social and cognitive psychology, medicine, journalism and legal studies (Arpac1, 2015).

Cohen et al. conducted studies on individual differences in cognitive motivation and described the need for 
cognition as a need to structure situations in meaningful and integrated ways, as an individual's need to understand and to make reasonable the experiential world.

An individual feels tension when this goal is not attained and this may increase efforts to understand the situation. The need for cognition is also a matter of individual autonomy and intrinsic motivation (Cacioppo et al., 1996). For instance, people with higher levels of intrinsic motivation often have higher levels of need for cognition as well (Cacioppo \& Petty, 1982).

\section{Methodology}

\subsection{Participants}

The present study was based on the relational screening model and the population was composed of the students studying at education faculties in Turkey. The study sample consists of 820 (522 female, 298 male) students enrolled in Gaziantep Faculty of Education in 2014-2015 academic year.

The data was collected through the convenient sampling method, from students enrolled in Psychological Counselling and Guidance (PCG), Classroom Teaching, Elementary Mathematics Education, Turkish Language Teaching, English Language Teaching, Social Sciences Teaching programmes at the Faculty of Education of Gaziantep University in the 2014-2015 academic year.

\subsection{Data Collection Tools}

The Thinking Styles Scale (TSS), the Need for Cognition Scale and a personal information form created by the researcher were used for the data collection process of the study. The original form of the Thinking Styles Scale was modified by Sternberg-Wagner (1992) in line with the Cognitive Self-Management Theory. There were 104 items in the original form of the Thinking Styles Scale, which were grouped under 5 main dimensions and 13 subdimensions. There was no total score to be obtained from the TSS; however, the subdimensions were calculated independently. Scores to be obtained from each item of the scale range from one to seven. Therefore, the highest score that can be obtained from a subdimension of the scale was 35 , while the lowest one was 5 . Higher points refer to higher levels of presence for the relevant thinking style. The thinking style with the highest score is described as the most frequent thinking style adopted by an individual (Fer, 2005).

The TSS was translated into Turkish by Buluş (2006) for the first time, decreasing the number of items to 65. In this study, this short form of the TSS, which was translated into Turkish by Buluş (2006), was used. This form of the TSS consists of 5 main dimensions and 13 subdimensions. In order to measure each thinking style through five different items, the form was created as a 7-point Likert scale. The scale was scored from 1 to 7 where 1 means "Not at all like me", 2 means "Not like me", 3 means "Barely like me", 4 means "Somewhat like me", 5 means "Fairly like me", 6 means "Very like me" and 7 means "Totally like me". Dimensions given in the scale were; A) Functions (legislative, executive, judicial), B) Forms (hierarchic, monarchic, oligarchic, anarchic), C) Levels (global, local), D) Areas (internal, external), E) Trends (liberal, conservative) thinking styles, respectively (Dinçer, 2009).

The original form of the Need for Cognition Scale (NCS) was created by Cacioppo and Petty (1982) in order to identify people's willingness toward the act of thinking and the levels of interest they have towards it. The Need for Cognition Scale consists of 18 items (half positive and half negative) and it is filled as a nine-step $(+4 /-4)$ Likert-type scale (Karakale, 2012).

"The Need for Cognition Scale" was translated into Turkish by Gülgöz and Sadowski (1995) and the translated version consists of 18 items and a single factor in total. Nine of the items are reversed, while the other nine items are straight forms. The first nine items were adapted as a rating scale and then a 5-point Likert-type scale was created by Demirci (1998). Scores to be obtained from Demirci's (1998) customized form vary between 18 (the lowest) and 90 (the highest). The scale consists of "Completely like me", "Like me", "Somewhat like me", "Not like me" and "Not at all like me" choices (Durmuş, 2013). In this study, the customized form of Demirci was used.

\subsection{Data Analysis}

The obtained data was statistically analyzed through a software program. Factorial structures of the scale, which were verified in terms of validity during the process of translation into Turkish, were not modified and no other factorial analysis was conducted during the study. Results of the factorial analyses conducted on the original forms of the scales were explained under the respective titles. In this way, the data analysis process continued using the original forms of the scales.

As the results of the test conducted to measure the normality of the data distribution of the study revealed that the normality values of Skewness-Kurtosis coefficients of the scores obtained from all subscales were between -1.5 
and +1.5 , it was concluded to perform parametric tests for the data analysis.

Table 2. Results of the sample skewness and kurtosis test conducted to measure normality in distribution of scores obtained from subdimensions of the thinking styles scale and the need for cognition scale by the students from the faculty of education

\begin{tabular}{|c|c|c|c|c|c|c|c|c|c|c|c|c|c|}
\hline 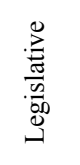 & 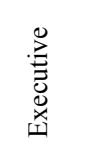 & 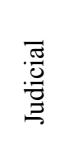 & 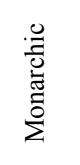 & 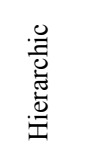 & 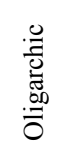 & 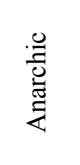 & $\begin{array}{l}\bar{\pi} \\
0 \\
0\end{array}$ & $\begin{array}{l}\text { ]్ల్ } \\
\text { త }\end{array}$ & 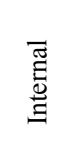 & 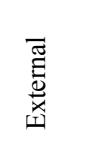 & $\begin{array}{l}\overline{\widetilde{J}} \\
\text { : } \\
.\end{array}$ & 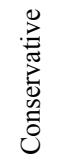 & $\begin{array}{l}\text { 己 } \\
Z_{1} \\
\frac{\pi}{0} \\
0 \\
0\end{array}$ \\
\hline-0.781 & -0.357 & -0.461 & -0.101 & -0.391 & 0.120 & 0.123 & -0.058 & 0.130 & -0.111 & -0.195 & -0.267 & 0.305 & 0.005 \\
\hline 1.119 & -0.121 & 0.037 & -0.135 & -0.131 & -0.259 & -0.199 & -0.409 & -0.240 & -0.403 & -0.228 & -0.369 & -0.596 & -0.229 \\
\hline
\end{tabular}

The test was used to identify the relationship between the scores obtained from the subdimensions of the Need for Cognition and the Thinking Styles Scales. In addition, an independent sample t-test was employed in order to identify whether the participant students' thinking styles and levels of need for cognition differ according to gender and a one-way variance analysis was performed to determine whether these two variables differ in terms of class levels, departments of study, secondary school majors, income levels of families and places where families have resided the longest.

\section{Results}

This section includes findings about the statistical analyses conducted on the data obtained through the scales and subscales used in the study for data collection.

1) Findings about the relationship between the scores obtained from the "Thinking Styles Scale" and the "Need for Cognition Scale" subdimensions:

"The Pearson Product-Moment Correlation Coefficient" was calculated in order to identify the relationship between the scores received by the students of the faculty of education in both the Thinking Styles and the Need for Cognition Scales. The results are given in Table 3.

Table 3. An analysis on the relationship between thinking styles and the need for cognition of the students of the faculty of education

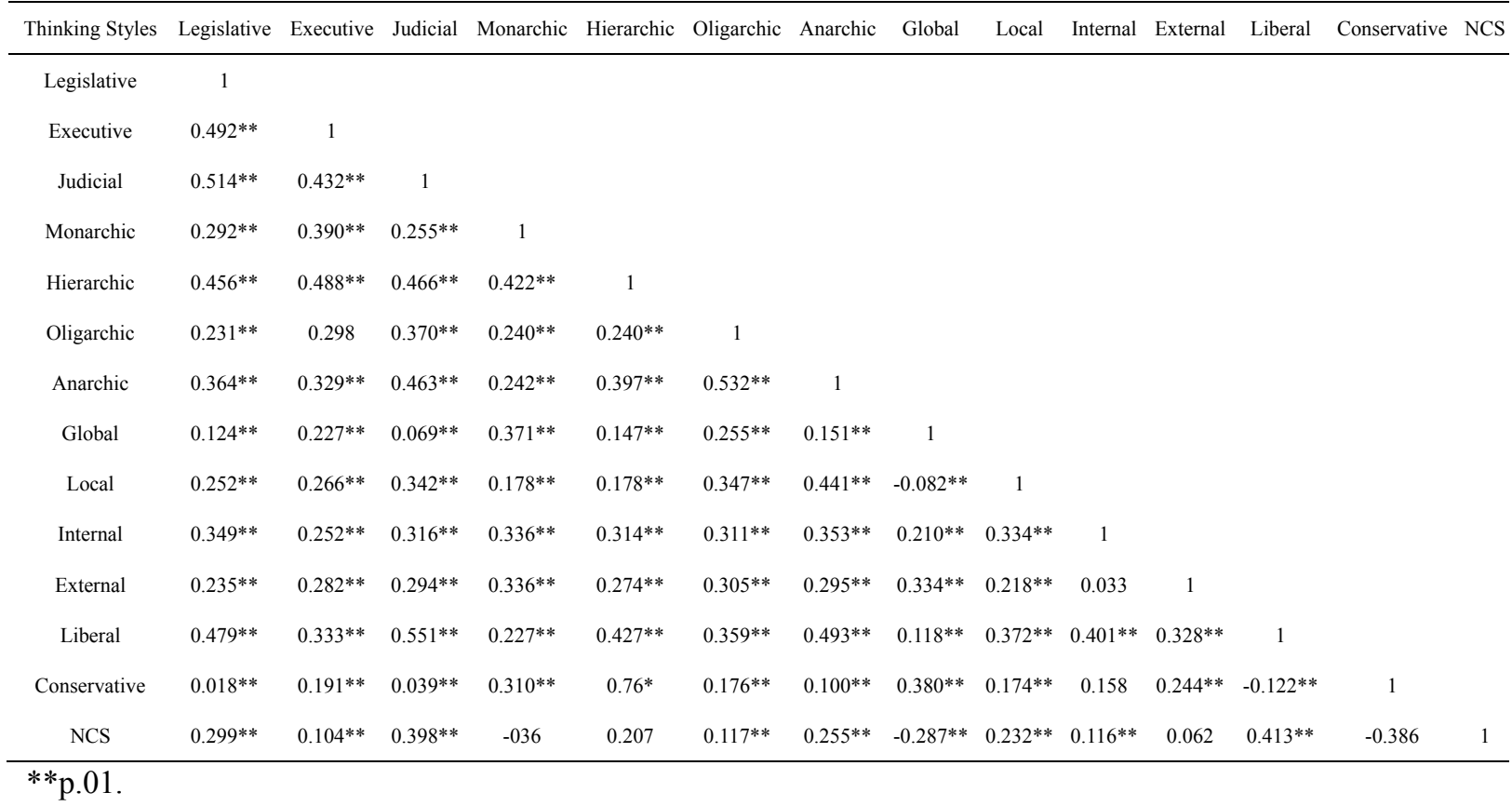


Considering the findings about the students of the faculty of education in terms of their thinking styles and need for cognition, it is seen that there is a positive relationship between preferred legislative $(\mathrm{r}=.299)$, executive $(\mathrm{r}=.104)$, judicial $(\mathrm{r}=.398)$, hierarchic $(\mathrm{r}=.207)$, oligarchic $(.117)$, anarchic $(\mathrm{r}=.255)$, local $(\mathrm{r}=.232)$, internal $(\mathrm{r}=.116)$, liberal $(r=.413)$ thinking styles and the need for cognition, while the relationship between global $(r=-.287)$, conservative $(\mathrm{r}=-.336)$ thinking styles and the need for cognitive is negative. In addition, there is no significant relationship between monarchic $(\mathrm{r}=-.036)$, external $(\mathrm{r}=.062)$ thinking styles and the need for cognition.

2) Findings about the differences in scores obtained from the "Thinking Styles Scale" and the "Need for Cognition Scale" subdimensions, according to gender:

T-test analyses were employed during the study in order to identify whether thinking styles of the students of the faculty of education and their levels of need for cognition differ according to the gender variable. The findings are given in Table 4.

Table 4. Results of the independent $t$-test regarding the scores obtained by the students of the faculty of education from subdimensions of the thinking styles scale according to the gender variable

\begin{tabular}{|c|c|c|c|c|c|c|c|}
\hline \multicolumn{2}{|c|}{ Scales and subscales } & \multicolumn{2}{|c|}{$\begin{array}{l}\text { Female } \\
\mathrm{n}=541\end{array}$} & \multicolumn{2}{|c|}{$\begin{array}{c}\text { Male } \\
n=279\end{array}$} & \multirow[b]{2}{*}{$\mathrm{t}$} & \multirow[b]{2}{*}{$\mathrm{p}$} \\
\hline \multirow{14}{*}{ Thinking Styles Scale } & & $\bar{X}$ & SS & $\bar{X}$ & SS & & \\
\hline & Legislative & 27.770 & 5.252 & 26.946 & 5297 & 2.12 & $0.034 *$ \\
\hline & Executive & 26.142 & 5.556 & 25.419 & 5.408 & 1.781 & 0.075 \\
\hline & Judicial & 25.558 & 6.165 & 25.286 & 5.196 & 0.629 & 0.529 \\
\hline & Monarchic & 22.345 & 5.548 & 22.035 & 5.548 & 0.749 & 0.454 \\
\hline & Hierarchic & 25.913 & 6.071 & 24.526 & 6.068 & 3.099 & $0.02 *$ \\
\hline & Oligarchic & 20.768 & 6.111 & 20.390 & 5.828 & 0.866 & 0.387 \\
\hline & Anarchic & 22.072 & 5.441 & 21.777 & 5.155 & 0.760 & 0.455 \\
\hline & Global & 20.216 & 6.725 & 20.541 & 6.182 & -0.501 & 0.617 \\
\hline & Local & 20.319 & 6.546 & 20.254 & 6.098 & 0.142 & 0.887 \\
\hline & Internal & 22.020 & 6.642 & 22.270 & 5.888 & -1.433 & 0.152 \\
\hline & External & 22.384 & 6.462 & 22.501 & 6.133 & -0.255 & 0.799 \\
\hline & Liberal & 25.051 & 6.257 & 24.759 & 6.047 & 0.647 & 0.518 \\
\hline & Conservative & 16.669 & 7.415 & 17.627 & 7.191 & -0.1788 & 0.074 \\
\hline
\end{tabular}

*p.05.

According to the findings of the independent t-test obtained from the subscales of the Thinking Styles Scale, judicial $(\mathrm{t}=2.12, \mathrm{p}<.01)$, executive $(\mathrm{t}=1.78, \mathrm{p}<.01)$ and hierarchic $(\mathrm{t}=3.09, \mathrm{p}<.01)$ thinking styles show significant differences according to the gender variable.

As it is seen in Table 4, female students have significantly higher score averages compared to male students in legislative (female $X=27.77$, male $X=26.94$ ) and hierarchic (female $X=25.91$, male $X=24.52$ ) subdimensions of the Thinking Styles Scale.

3) Findings about the differences in the scores obtained from the "Thinking Styles Scale" and the "Need for Cognition Scale" subdimensions according to the department of study:

A One-Way Variance Analysis (ANOVA) test was employed during the study in order to determine whether the thinking styles of students of the faculty of education and their levels of need for cognition differ according to the department that they study in. The findings are given in Table 5. 
Table 5. Results of the one-way variance analysis (ANOVA) regarding the scores obtained by the students of the faculty of education from subdimensions of the thinking styles scale according to the department of study

\begin{tabular}{|c|c|c|c|c|c|c|c|c|c|}
\hline Scales and Subscales & $\begin{array}{c}\text { RPD } \\
\text { (A) } n=150\end{array}$ & $\begin{array}{l}\text { CLASS } \\
\text { (B) } \\
\mathrm{n}=120\end{array}$ & $\begin{array}{c}\text { MATHS } \\
\text { (C) } \\
\mathrm{n}=134\end{array}$ & $\begin{array}{c}\text { TURKISH } \\
\text { (D) } \\
\mathrm{n}=232 \\
\end{array}$ & $\begin{array}{c}\text { ENGLISH } \\
(\mathrm{E}) \\
\mathrm{n}=70 \\
\end{array}$ & $\begin{array}{l}\text { SOCIAL SCIENCES } \\
\qquad \begin{array}{c}(\mathrm{F}) \\
\mathrm{n}=111\end{array} \\
\end{array}$ & $\mathrm{~F}$ & $\mathrm{p}$ & $\begin{array}{l}\text { Sign. } \\
\text { Differ }\end{array}$ \\
\hline & $\bar{X}$ & $\bar{X}$ & $\bar{X}$ & $\bar{X}$ & $\bar{X}$ & $\bar{X}$ & & & \\
\hline Legislative & 27.980 & 26.733 & 28.097 & 27.487 & 28.285 & 26.504 & 2.146 & 0.058 & \\
\hline Executive & 25.261 & 25.941 & 26.216 & 26.137 & 26.985 & 25.144 & 1.552 & 0.171 & \\
\hline Judicial & 25.614 & 26.041 & 25.462 & 25.038 & 26.557 & 24.846 & 1.226 & 1.236 & \\
\hline Monarchic & 22.137 & 22.875 & 23.164 & 22.051 & 21.814 & 21.243 & 1.889 & 0.094 & \\
\hline Hierarchic & 24.902 & 26.041 & 26.395 & 25.099 & 25.685 & 24.945 & 1.445 & 0.206 & \\
\hline Oligarchic & 19.954 & 21.741 & 21.470 & 20.750 & 19.814 & 21.765 & 2.576 & $0.025 *$ & $\mathrm{C}>\mathrm{A}$ \\
\hline Anarchic & 21.143 & 22.216 & 22.664 & 22.051 & 22.100 & 21.765 & 0.288 & 0.267 & \\
\hline Global & 19.993 & 20.633 & 20.731 & 20.004 & 19.557 & 20.774 & 0.552 & 0.737 & \\
\hline Local & 18.803 & 21.116 & 21.932 & 20.086 & 20.800 & 19.621 & 4.286 & $0.001 *$ & $\mathrm{~B}>\mathrm{A}$ \\
\hline Internal & 21.928 & 22.875 & 23.388 & 22.094 & 22.100 & 21.000 & 2.049 & 0.070 & \\
\hline External & 21.477 & 23.000 & 22.970 & 22.258 & 21.871 & 23.144 & 1.504 & 0.186 & \\
\hline Liberal & 24.817 & 25.366 & 24.858 & 24.767 & 25.885 & 24.603 & 0.558 & 0.732 & \\
\hline Conservative & 15.947 & 18.716 & 18.903 & 16.586 & 14.585 & 16.648 & 5.595 & $0.000 *$ & $\mathrm{C}>\mathrm{A}$ \\
\hline
\end{tabular}

*p.05.

As seen in Table 5, according to the One-Way Variance Analysis (ANOVA) conducted to identify any significant difference among the scores obtained by students of the faculty of education in terms of the departments they study at, the arithmetic means of oligarchic, local and conservative dimensions of the Thinking Styles Scale show statistically significant differences (Oligarchic: $\mathrm{F}=2.576$; 0.025, Local: $\mathrm{F}=4.286$; 0.001, Conservative: $\mathrm{F}=5.595$; 0.000 ). After this step, post-hoc analysis methods were employed to identify the group that caused this significant difference determined in the ANOVA.

In order to choose the right post-hoc multiple comparison method after the ANOVA, the hypothesis about the homogeneity of group distribution variances was firstly tested with the Levene's test and as a result, the variances were found to be homogenous. Then, the Scheffe multiple comparison method, which is widely used when variances show homogeneity was conducted. The Scheffe test was preferred as it is sensitive to alpha-type errors. The results of the Scheffe multiple comparison test are as follow:

According to the post-hoc Tukey test applied after the One-Way Variance Analysis (ANOVA) in order to identify the subgroups that show differences in scale scores according to department of study, a statistically significant difference of $(p<0.01)$ was identified in favor of local, conservative and oligarchic groups of thinking styles. Differences between PCG-Mathematics Teaching and PCG-Classroom Teaching pairs emerged against PCG.

4) Findings about the differences in scores obtained from "Thinking Styles Scale" and the "Need for Cognition Scale subdimensions according to the monthly income of students' families:

The One-Way Variance Analysis (ANOVA) test employed during the study to determine whether the thinking styles of the students of the faculty of education and their need for cognition differ according to monthly incomes of their families. The findings are given in Table 6 . 
Table 6. Results of the one-way variance analysis (ANOVA) regarding the scores obtained by the students of the education faculty from the thinking styles scale subdimension according to the monthly incomes of families

\begin{tabular}{|c|c|c|c|c|c|c|}
\hline Scales and Subscales & Variance Reason & Sum of Squares & S.D. & Average of Squares & $\mathrm{F}$ & $\mathrm{p}$ \\
\hline \multirow{3}{*}{ Legislative } & Intergroup & 356.556 & 2 & 178.278 & 6.482 & $0.002 *$ \\
\hline & Intragroup & $22,470.366$ & 817 & 27.504 & & \\
\hline & Total & $22,826.922$ & 819 & & & \\
\hline \multirow{3}{*}{ Executive } & Intergroup & 199.375 & 2 & 99.688 & 3.298 & $0.037 *$ \\
\hline & Intragroup & $24,698.814$ & 817 & 30.231 & & \\
\hline & Total & $24,898.189$ & 819 & & & \\
\hline \multirow{3}{*}{ Judicial } & Intergroup & 26.280 & 2 & 2 & 0.383 & 0.682 \\
\hline & Intragroup & $28,021.764$ & 817 & 817 & & \\
\hline & Total & $28,048.044$ & 819 & & & \\
\hline \multirow{3}{*}{ Monarchic } & Intergroup & 28.001 & 2 & 14.000 & 0.444 & 0.641 \\
\hline & Intragroup & $25,745.671$ & 817 & 31.512 & & \\
\hline & Total & $25,773.672$ & 819 & & & \\
\hline \multirow{3}{*}{ Hierarchic } & Intergroup & 157.126 & 2 & 78.563 & 2.116 & 0.121 \\
\hline & Intragroup & $30,339.064$ & 817 & 37.135 & & \\
\hline & Total & $30,496.190$ & 819 & & & \\
\hline \multirow{3}{*}{ Oligarchic } & Intergroup & 100.275 & 2 & 50.138 & 1.387 & 0.250 \\
\hline & Intragroup & $29,540.596$ & 817 & 36.157 & & \\
\hline & Total & $29,640.872$ & 819 & & & \\
\hline \multirow{3}{*}{ Anarchic } & Intergroup & 97.440 & 2 & 48.720 & 1.708 & 0.182 \\
\hline & Intragroup & $23,298.915$ & 817 & 28.518 & & \\
\hline & Total & $23,396.355$ & 819 & & & \\
\hline \multirow{3}{*}{ Global } & Intergroup & 49.087 & 2 & 24.544 & 0.573 & 0.564 \\
\hline & Intragroup & $35,015.902$ & 817 & 42.859 & & \\
\hline & Total & $35,064.989$ & 819 & & & \\
\hline \multirow{3}{*}{ Local } & Intergroup & 286.101 & 2 & 143.050 & 3.521 & $0.030^{*}$ \\
\hline & Intragroup & $33,195.294$ & 817 & 40.631 & & \\
\hline & Total & $33,481.395$ & & & & \\
\hline \multirow{3}{*}{ Internal } & Intergroup & 175.387 & 2 & 87.694 & 2.147 & 0.117 \\
\hline & Intragroup & $33,364.803$ & 817 & 40.838 & & \\
\hline & Total & $33,540.190$ & 819 & & & \\
\hline \multirow{3}{*}{ External } & Intergroup & 20.757 & 2 & 10.378 & 0.257 & 0.088 \\
\hline & Intragroup & $32,993.556$ & 817 & 40.384 & & \\
\hline & Total & $33,014.312$ & 819 & & & \\
\hline \multirow{3}{*}{ Liberal } & Intergroup & 185.578 & 2 & 92.789 & 2.434 & 0.088 \\
\hline & Intragroup & $31,139.567$ & 817 & 38.115 & & \\
\hline & Total & $31,325.145$ & 819 & & & \\
\hline \multirow{3}{*}{ Conservative } & Intergroup & 144.269 & 2 & 72.134 & 1.337 & 0.263 \\
\hline & Intragroup & $44,093.712$ & 817 & 53.970 & & \\
\hline & Total & $44,237.980$ & 819 & & & \\
\hline
\end{tabular}

*p.05.

According to Table 6 and the analysis on whether the students of the faculty of education show any difference in thinking style scores according to monthly incomes of their families, there is a significant difference between legislative and local thinking style scores. According to the results of the Tukey test conducted to examine the reason for difference, there is a significant difference between 500-1000 TL and $2000 \mathrm{TL}$ and above income groups in both thinking styles and the difference is in favor of the $2000 \mathrm{TL}$ and above income group.

5) Findings about the differences in scores obtained from the "Thinking Styles Scale" and the "Need for Cognition Scale" subdimensions according to the class level variable:

The One-Way Variance Analysis (ANOVA) test employed during the study to determine whether the thinking styles of students of the education faculty and their need for cognition differ significantly according to the class 
levels. The findings are given in Table 7.

Table 7. results of the one-way variance analysis (ANOVA) regarding the scores obtained by the students of the faculty of education from the need for cognition scale according to class level variable

\begin{tabular}{cccccccc}
\hline & Variance & Sum of Squares & S.D. & Average of Squares & F & p & Significant Difference \\
\cline { 2 - 7 } Need for Cognition & Intergroup & $1,146.403$ & 3 & 382.134 & 2.920 & 0.033 & \\
& Intragroup & $106,792.450$ & 816 & 130.873 & 2.920 & & $4>1$ \\
& Total & $107,938.852$ & 819 & & & & \\
\hline
\end{tabular}

*p.05.

Looking at Table 7, it is seen that students of the faculty of education show significant differences in the need for cognition scores according to the relevant class level. According to the results of the Tukey test conducted to examine the reason for difference, there is difference between the 1 st and the 4 th class levels and the difference is in favor of the 4 th grade students.

6) Findings about the differences in scores obtained from the "Thinking Styles Scale" and the "Need for Cognition Scale" subdimensions according to the place where students' families resided the longest:

The One-Way Variance Analysis (ANOVA) test employed during the study to determine whether the thinking styles of students of the faculty of education and their need for cognition differ according to the place where families have resided the longest. The findings are given in Table 8 .

Table 8. Results of the one-way variance analysis (ANOVA) regarding the scores obtained by the students of the faculty of education from the need for cognition scale according to the place where families have resided the longest

\begin{tabular}{cccccccc}
\hline & Variance & Sum of Squares & S.D. & $\begin{array}{c}\text { Average of } \\
\text { Squares }\end{array}$ & F & P & $\begin{array}{c}\text { Significant } \\
\text { Difference }\end{array}$ \\
\cline { 2 - 8 } Need for & Intergroup & 842.935 & 2 & 421.468 & 3,215 & $0.041^{*}$ & \\
Cognition & Intragroup & $107,095.917$ & 817 & 131.084 & 3,215 & $0.041^{*}$ & Province>Village \\
& Total & $107,938.852$ & 819 & & & & \\
\hline
\end{tabular}

*p.05.

Looking at Table 8, it is seen that students of the faculty of education show significant difference in the need for cognition according to the places where their families have resided the longest. According to the results of the Tukey test conducted to examine the reason for difference, there is a significant difference between village-town and province variables and the difference is in favor of the province variable.

\section{Discussion and Conclusion}

1) Discussion regarding the relationship between the scores obtained from the "Thinking Styles Scale" and the "Need for Cognition Scale" subdimensions:

It was examined whether there is a significant relationship between thinking styles of the students of the faculty of education and their need for cognition. A positively significant relationship was found between legislative, executive, judicial, hierarchic, oligarchic, anarchic, local, internal and liberal thinking styles and the need for cognition. According to this, it can be concluded that individuals with higher levels of need for cognition often prefer legislative, judicial, hierarchic, oligarchic, anarchic, local, internal and liberal thinking styles. Moreover, there is a significant negative relationship between the conservative thinking style and the need for cognition. In other words, the number of students from the faculty of education who prefer global and conservative thinking styles decreases as the need for cognition increases. As individuals with global thinking styles do not often fasten upon and question details but focus on the whole picture, the need for cognition in this group is assumed to be relatively less. Those with conservative thinking style prefer conventional methods and situations which do not require high levels of cognition, the need for cognition in this group is also seen rather low. There is no significant relationship between monarchic and external thinking styles and the need for cognition.

According to the literature review, no relational research with a comparison of these two variables has been conducted until now. 
2) Discussion regarding the differences in the scores obtained from the "Thinking Styles Scale" and the "Need for Cognition Scale" subdimensions, according to the gender variable:

The data regarding the differences among students' thinking styles in terms of the gender variable was analyzed and significant differences were found among legislative, executive and hierarchic thinking styles. This difference is in favor of the female students. According to this, it can be concluded that female students are more innovative, creative and self-driven compared to the male students. The reasons behind these gender-based differences can be the relations between societies and thinking styles, and the impact of culture on them, the patriarchal structure of our society, and the difference in parental behaviors toward boys and girls. Girls often tend to improve themselves, benefit from innovations and become independent based on a wish for freedom as they are often in the background in this cultural context.

According to the literature review, Önkuzu (2013) suggests a significant difference in favor of female students between their legislative, executive, monarchic and hierarchic thinking styles and the gender variable. In addition, Çubukçu (2004), Balgamış (2007), Kaya (2009), Balgamış and Baloğlu (2010), Bilgiç (2010), Çelik (2011), Özbaş, Uluçınar, and Sağır (2014) identified significant differences between thinking styles and gender. However, findings of this study contradict with the results of the studies about the impact of gender on differences in thinking styles, which were conducted by Gaffor (2007), Saracaloğlu, Yenice, and Karasakaloğlı (2008) and Kaya (2009).

On the other hand, the difference in students' levels of need for cognition based on the gender variable was not found significant in the study.

Looking at the literature, this study shares similarities with the studies conducted by Gülgöz and Sadowski (1995), Cenkseven and Akar (2006), Polat (2008), Sorhan (2014), Arpacı (2015) and Arpacı and Bardakçı (2015).

Furthermore, Gençdoğan (2001) and Demirtaş (2012) suggest that women have higher levels of need for cognition than men.

The study did not identify any significant relationship between the need for cognition and the gender variable. This finding is consistent with the expectations. As the need for cognition, which is closely related with cognitive activities, does not differ significantly by gender, particularly women in our society should be provided with more opportunities in scientific areas and encouraged to be involved in scientific activities. This is also significant for the welfare of the whole society (Sorhan, 2014).

3) Discussion regarding the differences in the scores obtained from the "Thinking Styles Scale" and the "Need for Cognition Scale" subdimensions, according to the department of study:

The study analyzed the relationship between thinking styles of the students of the faculty of education and the departments they study at. The findings were significant in oligarchic, local and conservative dimensions of the Thinking Styles Scale. According to the tests conducted to identify groups affected by the differences, in local, oligarchic and conservative thinking style categories a significant difference was determined between PCG-Classroom Teaching and PCG-Mathematics Teaching pairs, each in favor of PCG.

Looking at the literature; Sünbül (2004) suggests that there are significant differences in terms of departments of study between the group of oligarchic, hierarchic, liberal and monarchic thinking styles and the conservative thinking style. Likewise, Buluş (2005) also found significant differences among departments in terms of judicial, executive, monarchic, internal, global, local and conservative thinking styles. In yet another study, Buluş (2006) suggests that social sciences, natural sciences and physical education teacher candidates use the executive thinking style more than art teacher candidates.According to Dinçer (2009), the difference between thinking styles and the department of study was only seen in the "executive" thinking style. In the English Language Teaching-Mathematics Teaching pair, the difference was found significantly in favor of the former.

This study examined whether students of the faculty of education show differences by their departments in terms of the need for cognition and no significant difference was identified.

However, Gençdoğan (2001) identified a significant relationship between the need for cognition and the department of study. This difference between Psychological Counseling and Guidance Teachers and History Teachers was found significant in favor of the former. On the other hand, Sevinç (2005) found that the need for cognition scores are affected by the department of study and there is a significant difference between the students of the pre-school teaching department and those of the classroom teaching department in terms of the need for cognition.

4) Discussion regarding the differences in the scores obtained from the "Thinking Styles Scale" and the "Need for Cognition Scale" subdimensions, according to monthly incomes of the students' families: 
Whether the students of the faculty of education show any difference in thinking style scores in terms of monthly incomes of their families was analyzed and a significant difference was identified in legislative thinking style and local thinking style scores. According to the results of the Tukey test conducted to examine the reason for difference, there is a significant difference between 500-1000 TL and 2000 TL and above income groups. This difference is seen in favor of the $2000 \mathrm{TL}$ and above income group.

Looking at the literature; Saracaloğlu, Yenice, and Karasakaloğlu (2008) found out that thinking styles show differences according to the socio-economic levels. According to the study, the difference stems from the internal and conservative thinking style scores.

Dinçer (2009) examined the relationship between socio-economic perceptions and thinking styles of teacher candidates and found significant differences between the students who perceive themselves at the middle and high socio-economic classes and those who perceive themselves at the low and high socio-economic classes, in terms of liberal and anarchic thinking styles. It was identified that the students who perceive themselves at the high socio-economic class adopt the liberal and anarchic thinking styles more than others.

This study examined whether students of the faculty of education show differences by monthly incomes of their families in terms of the need for cognition and no significant relationship was identified between these two variables.

Likewise, Gençdoğan (2001) and Sorhan (2014) also did not identify any significant difference between the economic status (weak - moderate - good - very good) and the need for cognition.

5) Discussion regarding the differences in the scores obtained from the "Thinking Styles Scale" and the "Need for Cognition Scale" subdimensions, according to the class grade variable:

It was analyzed whether the students of the faculty of education show any difference in thinking style scores according to class levels and no significant relationship was identified.

However, Buluş (2005) discovered a significant relationship between thinking styles and the class level variable. According to Buluş (2005), there was a significant difference between the students of the first and the fourth grade, which was in favor of the latter. In addition, another significant difference was identified between these two groups of students in terms of the external thinking style and this difference was found in favor of the former group. Buluş (2006) also identified significant differences in terms of internal, external and conservative thinking styles. These differences were found significant in favor of fourth graders in terms of internal thinking style, while the difference in the conservative thinking style was in favor of the first graders. Dinçer (2009) found a significant difference only in the internal thinking style and in favor of the fourth grade students.

In addition, Canpolat (2011) identified significant differences between the third and the fourth grade students in terms of thinking styles. Canpolat found these significant differences in favor of the third grade students in terms of innovative, judicial, introvert and anomalous thinking styles.

This study examined whether students of the faculty of education show differences by class levels in terms of the need for cognition and a significant relationship was found between these two variables. According to the analyses, the difference identified between the first and the fourth grade students was in favor of the latter.

Looking at the literature; Gençdoğan (2011) suggests that the second grade students have lower levels of need for cognition than the third graders. However, the sample group of this study is limited as it did not include the students from the first and the fourth class levels. Therefore, it is difficult to claim any significant difference among class levels based on this study. On the contrary, Polat (2008) found no significant relationship between gender and thinking styles.

6) Discussion regarding the differences in the scores obtained from the "Thinking Styles Scale" and the "Need for Cognition Scale" subdimensions, according to the place where students' families have resided the longest:

Whether the students of the faculty of education showed any difference in thinking style scores according to the place where their families have resided the longest was analyzed and no significant relationship was identified. In addition, there is no literature analyzing the thinking styles and this aforementioned variable altogether.

However, a significant relationship was found between the need for cognition of students in the faculty of education and the place where students' families have resided the longest. According to the analyses, there is a significant difference between the village-town and province variables and the difference is in favor of the province variable.

Looking at the literature; Gençdoğan (2001) identified a significant relationship between the type of places (province-district-village) and the Need for Cognition Scale scores. Although no significant difference was found 
in terms of the need for cognition between those who have resided either in provinces or districts, it was identified that the others who have resided relatively longer in provinces show higher levels of need for cognition than those who have resided in villages for longer periods. Likewise, those who have resided longer in districts have higher levels of need for cognition compared to those who have resided longer in villages.

\section{References}

Akman, Ö. (2016). Social-CognitiveCareer Model for Social Studies Teacher Candidates' Leadership in Educational Technology. International Journal of Progressive Education, 12(3).

Akman, O. (2017). Teacher Candidates' Attitudes, Knowledge Levelsand Sensitivities towards Environmental Problems. Journal of Education and Practice, 8(10), 1-16.

Akman, O., \& Alagoz, B. (2017). A Study on Environment-Oriented Knowledge, Attitudeand Behavior Level of Teacher Candidates. Journal of Education and Practice, 8(7), 229-245.

Arıol, Ş. (2009). Matematik Öğretmen Adaylarının Bütüncül (Holistik) Ve Analitik Düşünme Stillerinin Matematiksel Problem Çözme Becerilerine Etkisi. Yüksek Lisans Tezi, Hacettepe Üniversitesi Sosyal Bilimler Enstitüsü, Ankara, ss. 4.

Arpac1, D. (2015). An investigation on the relationship between prospective teachers' early teacher identity and their need for cognition (Unpublished MA thesis). Gaziantep University, Graduate School for Educational Sciences, Gaziantep. https://doi.org/10.11114/jets.v4i3.1176

Arpacı, D., \& Bardakçı, M. (2016). An investigation on the relationship between prospective teachers' early teacher identity and their need for cognition. Journal of Education and Training Studies, 4(3), 9-19. https://doi.org/10.11114/jets.v4i3.1176

Balgalmıs, E. (2007). Eğitim Yöneticilerinin Düşünme Stilleri ile Basa Çıkma Davranışları Arasındaki İlişki. Yüksek Lisans Tezi, Gazi Osman Paşa Üniversitesi Sosyal Bilimler Enstitüsü, Tokat, ss.7-19.

Balgamış, E., \& Baloğlu, E. (2010). Eğitim Yöneticilerinin Düşünme Stilleri Açısından Çeşitli Değişkenlere Göre İncelenmesi. Hacettepe Üniversitesi Eğitim Fakültesi Dergisi, 38, 1-10.

Bilgiç, E. (2010). İlköğretim Okulunda Görevli Yöneticilerin ve Öğretmenlerin Düşünme Stillerinin Karşılaştırılması (Adana İli Örneği). Yüksek Lisans Tezi, Niğde Üniversitesi Sosyal Bilimler Enstitüsü, Niğde.

Buluş, M. (2005). Düşünme stilleri ölçeği'nin güvenirliği ve geçerliği, akademik başarı ve öğretmen adayları özellikleri. Ege Eğitim Dergisi, 1(6), 1-24.

Cacioppo, J. T., \& Petty, R. E. (1982). The need for cognition. Journal of Personality and Social Psychology, 42(1), 116-131. https://doi.org/10.1037/0022-3514.42.1.116

Cacioppo, J. T., Petty, R. E., Feinstein, J. A., \& Jarvis, B. G. (1996). Dispositional differences in cognitive motivation: The life and times of individuals varying in need for cognition. Psychological Bulletin, 119(2), 197-253. https://doi.org/10.1037/0033-2909.119.2.197

Canpolat, N. (2011). Matematik Öğretmen Adaylarının Teknolojik Pedagojik Alan Bilgileri İle Düşünme Stilleri Arasındaki İlişkinin Incelenmesi. Yüksek Lisans Tezi, Selçuk Üniversitesi, Eğitim Bilimleri Enstitüsü, Konya, ss. 4.

Çelik, D. (2016). 11. Sinıf Öğrencilerinin Düşünme Stilleri, Öğrenme Stratejileri ve Düşünme Stilleri ile Öğrenme Stratejileri Arasındaki İlişki. Yüksek Lisans Tezi, Pamukkale Üniversitesi, Eğitim Bilimleri Enstitüsü, Denizli.

Cenkseven, F., \& Akar, V. R. (2006), Ergenlerin düşünme gereksinimine cinsiyetlerine göre problem çözme becerilerinin karşılaştırılması. Eurasian Journal of Educational Research, 25, 45-53.

Çubukçu, Z. (2004). Öğretmen Adaylarının Düşünme Stillerinin Öğrenme Biçimlerini Tercih Etmelerindeki Etkisi. XIII. Ulusal Eğitim Bilimleri Kurultayı, Malatya, ss. 6-9.

Dinçer, B. (2009). Öğretmen Adaylarının Düşünme Stilleri Profillerinin Çeşitli Değişkenler Açısından Değerlendirilmesi. Yayınlanmış Yüksek Lisans Tezi, Adnan Menderes Üniversitesi, Sosyal Bilimler Enstitüsü, Aydın, ss. 36-37.

Durmuş, E. (2013).Cinsel taciz: Üniversite öğrencilerinin alg1 ve tepkileri. İnönü Üniversitesi Eğitim Fakültesi Dergisi, 14(1), 15-30.

Fer, S. (2005). Düşünme stilleri envanterinin geçerlik ve güvenirlik çalışması. Kuram ve Uygulamada Eğitim 
Bilimleri, 5(1), 31-67.

Gafoor, A. K. (2007). Does Present Education Favour Executive and External Styles of Thinking at the Expense of Achievement In Science? Paper Presented in International Conference on Educational Research in Era of Globalization, November, 28-30, Periyar University, Salem, India.

Gençdoğan, B. (2001). Üniversite öğrencilerinin düşünme ihtiyaçlarının bazı değişkenler açısından İncelenmesi. Cumhuriyet Üniversitesi Sosyal Bilimler Dergisi, 25, 227-234.

Gülgöz, S., \& Sadowski, C. J. (1995). Düşünme ihtiyacı ölçeğinin Türkçe uyarlaması ve öğrenci başarı göstergeleri ile korelasyonu. Türk Psikoloji Dergisi, 10(35), 15-24.

Karabulut, E. (2014). Psikolojik Danışman Adaylarının Duygusal Zekâ Düzeyleri ile Düşünme Stilleri Arasındaki ilişski. Yüksek Lisans Tezi, Dokuz Eylül Üniversitesi Eğitim Bilimleri Enstitüsü, İzmir, ss. 54.

Karakale, S. (2012). Üst bilişsel farkındalık, zekâ, problem çözme algısı ve düşünme ihtiyacı arasındaki bağlantılar. Ĕgitim ve Bilim, 164(37), 243.

Kaya, B. (2009). İlköğretim 6-7-8. Sınıf Öğrencilerinin Düşünme Stilleri İle Matematik Akademik Başarılarının Okul Türüne, Cinsiyete Ve Sınıf Düzeyine Göre İncelenmesi. Yüksek Lisans Tezi, Yıldız Teknik Üniversitesi Sosyal Bilimler Enstitüsü, İstanbul.

Oflar, Y. (2010). İlköğretim Okulu Öğretmenlerinin Düşünme Stilleri. Yüksek Lisans Tezi, Abant Baysal Üniversitesi Sosyal Bilimler Enstitüsü, Bolu, ss.12-23.

Önkuzu, E. (2013). Hazırlık Sinıfi Öğrencilerinin Öğrenme Ve Düşünme Stilleri İle Yabancı Dilde Kelimenin Anlamın Tahmin Etme Başarıları Arasındaki İlişki. Yüksek Lisans Tezi, Gaziosmanpaşa Üniversitesi, Eğitim Bilimleri Enstitüsü, Tokat.

Özbaş, N., \& Uluçınar, S. Ş. (2014). Sınıf öğretmenlerinin düşünme stilleri ve kullandıkları ölçme-değerlendirme yöntemleri arasındaki ilişkinin incelenmesi. Ondokuz Mayıs Üniversitesi Eğitim Fakültesi Dergisi, 33(1), 305-321.

Özden, Y. (2005). Ögrenme ve Ögretme. Pegem Yayınları, Ankara, ss.139.

Polat, R. (2008). Sinıf Öğretmenliği Öğrencilerinin Bazı Sosyo-Demografik Özellikleri Ve Düşünme İhtiyacına Göre Problem Çözme Becerilerinin Incelenmesi. Yüksek Lisans Tezi, Çukurova Üniversitesi Sosyal Bilimler Enstitüsü, Adana, ss.21-28.New York: Guilford Press.

Saracaloğlu, A. S., Yenice, N., \& Karasakaloğlu, N. (2008). Eğitim fakültesi öğrencilerinin düşünme stillerinin çeşitli değişkenler açısından karşıllaştırılması. Uluslararası Sosyal Araştırmalar Dergisi, 1(5), 732-75.

Sevinç, M. (2005). İlköğretim Bölümü Öğretmen Adaylarının Düsünme İhtiyact. 14. Ulusal Eğitim Bilimleri Kongresinde Sunulan Bildiri, 28-30 Eylül 2005. Pamukkale Üniversitesi, Denizli.

Sorhan, G. (2014). Üniversite Öğrencilerinin Düşünme İhtiyaçlarının Temel Psikolojik İhtiyaçlarının Doyumuna Göre Incelenmesi. Yüksek Lisans Tezi, Gazi Üniversitesi Eğitim Bilimleri Anabilim Dalı, Ankara.

Sternberg, R. J. (1997). Thinking Styles. Cambridge University Press, New York. https://doi.org/10.1017/CBO9780511584152

Sünbül, A. M. (2004). Düşünme stilleri ölçeğinin geçerlik ve güvenirliği. Eğitim ve Bilim, 132(29), 25-42.

Tok, E. (2010). Okul öncesi 1. sınıf öğretmen adaylarının düşünme ihtiyaçları ve düşünme ihtiyacına yönelik görüşleri (Pamukkale Üniversitesi örneği). Uluslar Arası İnsan Bilimleri Dergisi, 7(2), 47.

\section{Copyrights}

Copyright for this article is retained by the author(s), with first publication rights granted to the journal.

This is an open-access article distributed under the terms and conditions of the Creative Commons Attribution license (http://creativecommons.org/licenses/by/4.0/). 